\title{
Failure of Brand Intoxication with the Mediating Effect of Ad Skepticism
}

\author{
Rafique Ahmed Khuhro ${ }^{1}$ \\ Niaz Ahmed Bhutto ${ }^{2}$ \\ Irshad Hussain Sarki ${ }^{3}$
}

\begin{abstract}
Brands still have not intoxicated the all segments of customers, yet there are people who have motivations to escape from brand. This study explores the mediating role of ad skepticism between self-image congruency, product knowledge and brand escapism motivation. The other purpose is to see the direct relation of product knowledge and self-image congruency on brand escapism motivation. A Study of 267 mobile phone users is conducted, who use iconic and less iconic mobile phone brands. Proposed relationships were empirically tested through SPSS and SPSS Macro for Multiple Mediation. People in Pakistan consider mobile phone brands as their social status, due to this their beliefs and disbeliefs about advertising and motivation in brand escapism are helpful to understand. Pakistan is a developing country, consumers are not so much brand conscious and do not pay attention to advertising issues like developed countries. Because of this mediating effect of ad skepticism is not supported. The results support the effects of self-image congruence and product knowledge on the brand escapism motivation but not on the ad skepticism.
\end{abstract}

Keywords: Brand Escapism Motivation, Ad Skepticism, Self-Image Congruence, Product Knowledge

https://doi.org/10.30537/sijmb.v2i1.90

${ }^{1} \mathrm{PhD}$ Scholar at Sukkur Institute of Business Administration, rafique.khuro@iba-suk.edu.pk

${ }^{2}$ Associate Professor at Sukkur Institute of Business Administration

${ }^{3} \mathrm{PhD}$ Scholar at Sukkur Institute of Business Administration 


\section{Introduction}

Escapism means that most people have, due to unsatisfying life circumstances, again and again cause to leave the reality in which they live in a cognitive and emotional way (Henning \& Vorderer, 2001). Escapist may do some activities, such as playing video games, watching $\mathrm{TV}$, etc. while non-activities may be daydreaming, waiting, sitting and doing nothing or staring out a window.

Brands are developed to make ease in consumer decision making and save it from perceived risk (Cox \& Rich, 1964). Brand awareness make possible for marketers to get consumers decisions taken more faster (Macdonald \& Sharp, 2000). Considering this, more emphasis is placed on brand awareness, and it creates consumer brand confusions (Foxman, Berger, \& Cote, 1992). However a halo of resemblance is created because of the similar attributes, content etc. and all this leads to confusion (Kapferer, 1995). Brand confusion creates dissatisfaction to some consumers (Foxman, Muehling, \& Berger, 1990), which motivate customers to escape from brands. Escapism means that most people have, due to unsatisfying life circumstances, again and again cause to leave the reality in which they live in a cognitive and emotional way (Henning \& Vorderer, 2001). Escapist may do some activities, such as playing video games, watching TV, etc. while non-activities may be daydreaming, waiting, sitting and doing nothing or staring out a window.

This is similar with our operational definition of escapism; people due to unsatisfying behavior with brands are motivated to escapism. People escape from brands and use the traditional methods of purchasing butter and honey in rural areas in Pakistan due to lack of trust of originality.

When consumers feel themselves as powerless, they try to regain the wellbeing and degree of self-empowerment, for this consumers mostly find ten remedies and escapism is one of them (Henry \& Caldwell, 2006). Motivation in escapism is such a way which gives pleasure or any mental health (Labrecque, Krishen, \& Grzeskowiak, 2011). Brands can as well fulfill this escapism motivation such as giving pleasure in using web brands (Mathwick \& Rigdon, 2004); sports fandom, like Nike or Harley Davidson (Wann, Allen, \& Rochelle, 2004); building communities (Kozinets, 2002).

A healthy research work is conducted to see the ad brand relation, some of it is, retrieval cues and brand evaluation (Keller, 1987); advertising and brand purchase (Tellis, 1988); advertising costs and brand perceptions (Kirmani, 1990); ad attitude and brand attitude (Phelps \& Thorson, 1991); comparative advertising and brand positioning (Pechmann \& Ratneshwar, 1991); retail advertising and brand sale (Bemmaor \& Mouchoux, 1991); advertising and brand switching (Deighton, Henderson, \& Neslin, 1994); advertising and 
brand image (Meenaghan, 1995); advertising and brand equity (Cobb-Walgren, Ruble, \& Donthu, 1995); generic advertising and impact of branding (Brester \& Schroeder, 1995); advertising and consumer brand choice (Mela, Gupta, \& Lehmann, 1997); advertising and brand gender perception (Till \& Priluck, 2001); brand reputation and advertising (Chaudhuri, 2002); 3-D advertising and brand attitude (Li, Daugherty, \& Biocca, 2002); advertising and brand linking (Casswell \& Zhang, 2002); advertising repetition and brand familiarity (Campbell \& Keller, 2003); ad brand incongruency (Dahlén \& Lange, 2004); advertising, brand loyalty and pricing (Chioveanu, 2008). All these research works discuss the relations or linkages between advertising and brands.

Skepticism and escapism are the areas which have not been explored in depth, very thin literature is available to discuss. Escapism and brand is studied by (Labrecque et al. 2011), they have checked brand loyalty and effects of escapism motivation and conformity motivation. While another study is conducted by (Khuhro, Bhutto, Sarki, and Shaikh 2012), they have carry forwarded the future research direction of (Labrecque et al., 2011) and tested the same model with iconic and less iconic brand.

Advertising skepticism effects are not tested with brand, only efforts are taken to measure ad skepticism, some of them works are ad skepticism in general (Obermiller \& Spangenberg, 1998); persuasive advertising and scale development of advertising skepticism (Koslow, 2000); ad skepticism and intergenerational influences (Obermiller \& Spangenberg, 2000); scale development of social ad skepticism (Thakor \& Goneau-Lessard, 2009).

Both constructs; escapism motivation and ad skepticism are not researched as is the advertising and brand relations. This study is focusing on the escapism motivation in brands and mediating role of ad skepticism. The purpose of this paper is twofold, first is to know the mediating effect of ad skepticism between self-image congruency, product knowledge and brand escapism motivation while second is to see the direct relation of product knowledge and self-image congruency on brand escapism motivation.

\section{Literature Review}

\section{i) Self-image Congruence}

Self-image or self-concept is defined as the totality of the individual's thoughts and feelings having reference to himself as an object (Sirgy, 1982). While self-image congruence refer to the match between consumers' self-concept (actual, ideal etc.) and the user image of a given product, band, store etc. (Sirgy, Grewal, \& Mangleburg, 2000).

There can be high level of self-image congruity and low level of self-image congruity in consumers. Those consumers belongs to high level of self-image congruity are tend to like more brand and gain more satisfaction than low level of self-image congruity (Jamal \& Goode, 2001); the authors have found strong relationship between self-concept and brand preferences; 
brand preferences may be on the basis of symbolic or functional properties, with relation to self-concept symbolic properties plays vital role. Their study has also found the strong relationship between the self-congruency and consumer satisfaction, in which image congruity has more impact on consumer satisfaction.

Person intend to purchase those brands which closely match with his own personality and are also connected with the self-image or self-concept, it has different conceptualizations such as, actual self, ideal self, social self, ideal social self (Schiffman \& Kanuk, 2000). Brands are attached emotionally with human as are his or her family members, because of this high congruity has the higher quality relationship with brand and it is having positive effect on brand loyalty. Self-congruity has direct link to brand loyalty and functional congruity is linked to brand loyalty indirectly, it may vary in terms of low and high involvement products (Kressmann et al., 2006).

There can be ad-brand incongruences especially when advertiser provides entire different message, such as a man in underwear ready for work or an ad of car and happy army but no any car image. Incongruent ad can bring novelty in brand communications but it can also create complexity in advertising messages. Advertising does not affect negative to established brands, marketers use advertising for established brands as a tool to change brand schemata and providing flexibility in brand knowledge structure. Ad linking plays vital role in ad credibility while ad credibility has negative effect on ad-brand incongruences; high involvement products' credibility is affected more than low involvement (Dahlén, Lange, Sjödin, \& Törn, 2005).

Advertising try to give direction to brands as companies wants, in advertising absence brand can exist but not as per the will of marketer, because advertising is the main component of image creation. There are two schools of thoughts in advertising effectiveness, one is cognitive, and the other is behavioral or brand image school. Cognitive school believes the role of advertising should be rational and by this consumer will tend to buy more. While other school points out that advertising should build a relationship between the consumer and brand, it brings the concept of personality of brands while cognitive school favors the functional congruity which refers to consumers' preference to brand performance. On the other hand behavioral school discusses of self-congruity which focuses on consumers cues and matches with brand which are communicated through advertising. Advertising tries to combine both think and feel (cognitive and behavioral) but yet disbeliefs exits (Meenaghan, 1995).

\section{ii) Product Knowledge}

There are three types of product knowledge, i) product experience; ii) subjective knowledge; iii) objective knowledge. Product experience is related with the possession of product or 
gaining knowledge after usage. Subjective knowledge refers to consumer's familiarity with the brand and its focus is on the motivational aspect. Objective knowledge is related with the information processing ability of consumers (Park \& Moon, 2003). In this study general aspect of product knowledge is used.

(Friestad and Wright 1995) have tried to investigate the advertising influences on audiences, for this they have split audiences into two parts, lay and researchers. Persuasion knowledge is the parameter on which it is studied. With these parameters author has found that researchers are more tend to be persuaded through science knowledge and they vary within their group while lay are persuaded through folk knowledge and they are consistent within their groups. Too much product knowledge can dilute the intentions to purchase new product and more product knowledge may leads to product susceptibility because individuals may gain irrelevant knowledge (Lai, 1991).

Theory supports that in traditional case consumers have many choices and make a selection while other aspect is that consumer make selection from given information or product knowledge as of being freedom to choose, and this right to choose is enriched through advertising which reduces consumer's cost and increases consumer's welfare. In this situation consumer is motivated to advertising. But not all advertisings are accurate that is the reason that consumers process their information, which is called defensive motivation. Consumers go for skepticism as marketers try to sell them instead of informing (Koslow, 2000) .

\section{iii) Ad Skepticism}

Skepticism and general attitude towards something are separate (Obermiller \& Spangenberg, 1998) ; a considerable work has been conducted to investigate the attitudes towards business and advertising such as (Barksdale \& Darden, 1972); (Gaski \& Etzel, 1986); (Muehling, 1987a). Ad skepticism is constrained to advertising and not for all kind of communications. It is also conceptualized as market place belief (Obermiller \& Spangenberg, 1998).

Disliking and believability are different with reference to skepticism. Ad skepticism and attitude towards advertising are related but separable constructs. Attitude towards advertising is studied, such as (Bauer et al. 1968) who proposed a construct of two dimensions, (Sandage and Leckenby 1980) proposed two dimensional conceptualization (Muehling, 1987b) developed a scale which could measure the cross sectional beliefs about advertising.

Skepticism toward advertising in general is defined as the tendency toward disbelief of advertising claims (Obermiller \& Spangenberg, 1998). Another study of (Obermiller and Spangenberg 2000) have worked on the intergenerational influences and determined ad skepticism as a separate construct from skepticism towards other sources of product 
information; their study found that children were less skeptical than their mothers. By considering gender the correlation was tested between children and parent. Male children and parent was having strong positive correlation while females were having strong correlation with fathers. Interrelationship between ad skepticism and other sources of product information was checked by classifying high and low skepticism. People high in skepticism are found high in other sources as well. Older people are more skeptical, high correlation between advertising and sales people was also found. Skepticism towards advertising overlaps to some extend with more general attitude towards business and marketing. Some evidence was found in intergenerational transfer of skepticism towards advertising but it was not so strong.

(Thakor and Goneau-Lessard 2009) have studied the effects of peer influence, parental influence, and personality variables to the social advertising skepticism. Social ads are different than commercial, they try to discourage behaviors which are risky such as smoking and encourage behaviors which are effortful such as blood donations. Modest correlation was in their research between social ad skepticism and commercial ad skepticism; the authors have taken both construct as separate one.

Ad-brand incongruence can have both positive and negative effects in established and less established brands. Ad incongruence may occur when an advertiser communicates a message of a man in underwear ready for work or an ad of car in which a happy army is shown not the car. Advertising does not have negative effect to established brands rather it may be used to change consumers' brand schema and it also provides flexibility in brand knowledge structure. Ad linking plays vital role in ad credibility, while ad credibility has negative effect on adbrand incongruences. High involvement products affect more on ad credibility. Incongruent ad brings novelty in brand communications but creates complexity in the advertising (Dahlén et al., 2005).

Most new products fail; for reducing it brand extensions are used. There may be similar and dissimilar brand extensions. Ad spending places positive effect on similar brand extensions. Dissimilar brand extensions lead to brand extensions skepticism due to large ad expenditure (Taylor \& Bearden, 2003).

Regulations are created when consumers are more skeptics because they verify ad claims. If ad claims are difficult to verify it creates more tendencies towards skepticism, Ads have two characteristics, subjective claims and objective claims. Objective claims contain more information in ads than subjective claims. Consumers can be divided on the basis of economies; such as former Soviet-bloc and developed market economies, skepticism in developed market economies is found more due to wide verity of brands and free choice (Feick \& Gierl, 1996). 
There is a close linkage between ethnocentrism and attitude towards brands; high ethnocentric consumers understand purchasing foreign brands is wrong while not the non-ethnocentric. This is the same case with ads of foreign brands, ethnocentric consumers show skepticism; it may be more or less with reference to low and high ethnocentrism. Ad influence is more on attitude towards brands in developing countries because consumers rely on information provided in ad rather than direct experience. Expert messages and arguments based appeals becomes more effective and lack of information in ad motivates in new markets (Feick \& Gierl, 1996).

Cause-related marketing (CRM) is used by companies to increase their profits by giving some margins, i.e. Surf excel launched the campaign for special children. It also creates skepticism towards ad, particularly to cause related marketing ads. It is specially increased when sin industries try to promote CRM activities, this can be the case, if any Tabaco company raise funds for cancer. This CRM ad skepticism can be reduced by providing high level of knowledge in ads and using emotional ads instead of attention-getting ads (Singh, Kristensen, \& Villasenor, 2009).

\section{Hypothetical Model}

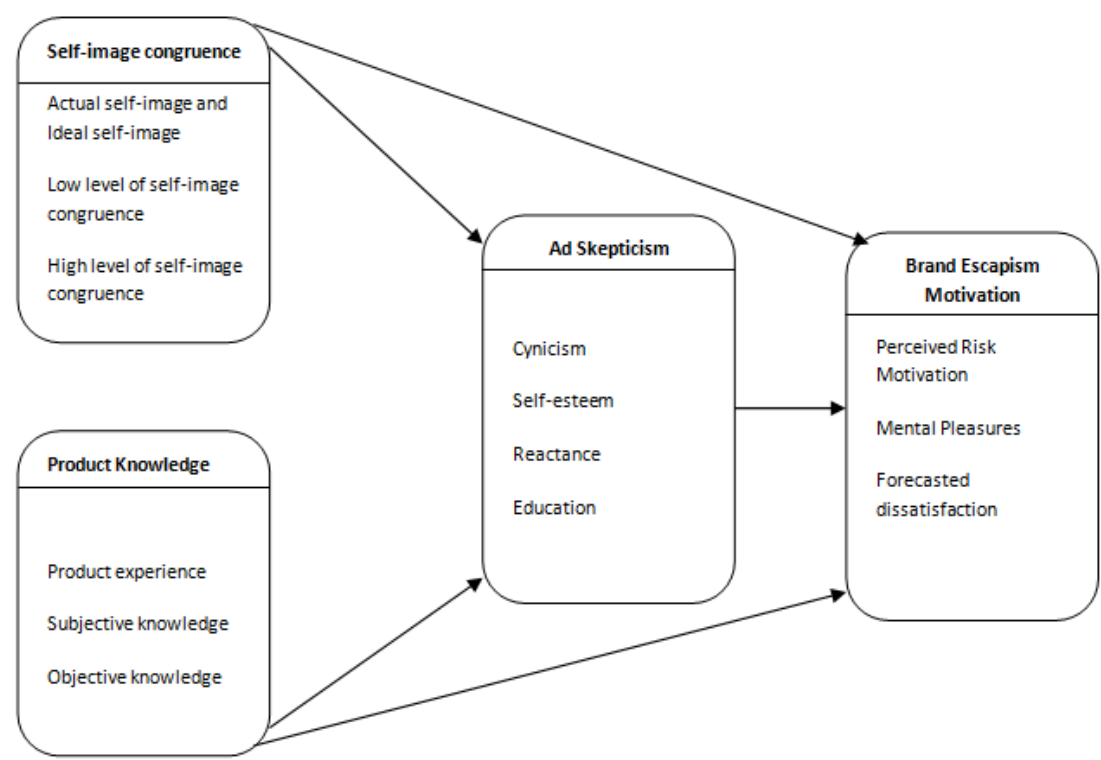

Self-image congruence and product knowledge are independent variables, while ad skepticism is playing as mediating role and brand escapism motivation is the dependent variable.

H1 Consumer being motivated with his self-image congruence does not care for social match up and it strengthen the positive effect on brand escapism motivation 
H2 Ad skepticism has mediating effect between self-image congruence and brand escapism motivation.

$\mathrm{H} 3$ Consumer is escaping from brands when halo of resemblance is created with more product knowledge that creates positive effect on brand escapism motivation

H4 Ad skepticism has mediating effect between product knowledge and brand escapism motivation.

\section{Methodology}

This is an empirical study, which examines the mediating effect of ad skepticism between self-image congruence and brand escapism motivation; product knowledge and brand escapism motivation. Survey method was selected to collect the data from the Pakistani university students, convenience sampling is used, and total sample in study is 267. Male response rate is more than female, 237 male have responded while only thirty female have participated in the study. The area is divided into two broad categories which are urban and rural, the age is categorized into four parts, the education is as well divided into four divisions, the largest sample size is from the master holders, the age, area and education distribution data is given below.

\begin{tabular}{|l|l|l|l|l|l|}
\hline Age & N & Area & N & Education & N \\
\hline less than 18 & 49 & Rural & 114 & less than graduation & 67 \\
19-25 & 159 & Urban & 153 & Graduation & 55 \\
$26-35$ & 42 & Total & 267 & Masters & 129 \\
more than 35 & 17 & & & MS PhD & 16 \\
Total & 267 & & & Total & 267 \\
\hline
\end{tabular}

Instrument is used to measure four constructs which are self-image congruence, product knowledge, band escapism motivation and ad skepticism. The first three constructs are checked with the help of scale of (Labrecque et al., 2011) and ad skepticism is measured through the scale of (Obermiller \& Spangenberg, 1998). Scale contains five point likert scale and responses consists of from Strongly Disagree to Strongly Agree. All the proposed relationships were empirically tested through SPSS 18.

\section{Results and Analysis}

The four constructs were containing twenty four items; ad skepticism was having nine; selfimage congruity six; escapism motivation five; and product knowledge four. The exploratory factor analysis was run to test the scale adoptability in Pakistani culture and consumer approach. Ad skepticism and escapism motivation are found the most valid scale and their all items are loaded on their constructs. Self-image congruity two items were dropped which are 
1) The image of the mobile phone brand is consistent with my self-image, 2) The typical person who uses mobile phone matches how I like to see myself, while four items are loaded to its construct. Product knowledge two items have been loaded and two have been dropped which are 1) I feel very confident about my ability to tell the difference in quality among different land line telephones (Landline telephone sets not the services) and 2) I have a lot of knowledge about how to select the best brand of land line telephone to suit my needs (Landline telephone sets not the services).

\begin{tabular}{|c|c|c|c|c|}
\hline \multicolumn{5}{|l|}{ Table 1Rotated Component Matrix } \\
\hline & \multicolumn{4}{|c|}{ Component } \\
\hline & 1 & 2 & 3 & 4 \\
\hline $\begin{array}{l}\text { Advertising is a reliable source of information about the quality and } \\
\text { performance of products }\end{array}$ & .638 & & & \\
\hline Advertising's aim is to inform the consumer & .636 & & & \\
\hline I feel I have been accurately informed after viewing most advertisements & .622 & & & \\
\hline I believe advertising is informative & .622 & & & \\
\hline Most advertising provides consumers with essential information & .595 & & & \\
\hline Advertising is the truth well told & .585 & & & \\
\hline In general, advertising presents a true picture of the product being advertised & .584 & & & \\
\hline Advertising is generally truthful & .565 & & & \\
\hline We can depend on getting the truth in most advertising & .514 & & & \\
\hline The typical person who owns a mobile phone matches how I see myself & & .894 & & \\
\hline I can identify myself with the people who own mobile phone & & .816 & & \\
\hline I aspire to be like those who use smart mobile phone & & .816 & & \\
\hline People who own mobile phone are like the person that I like to be & & .645 & & \\
\hline I use my mobile phone because it takes me into another world & & & .783 & \\
\hline I use my mobile phone because it makes me feel less lonely & & & .762 & \\
\hline I use my mobile phone because it stimulates me & & & .757 & \\
\hline I use my mobile phone because it arouses my emotions and feelings & & & .717 & \\
\hline I use my mobile phone so I can escape from Reality & & & .471 & \\
\hline $\begin{array}{l}\text { If friends asked me about land line telephone, I could give them advice about } \\
\text { different Brands (Landline telephone sets not the services) }\end{array}$ & & & & .673 \\
\hline I feel very knowledgeable about the mobile phones & & & & .592 \\
\hline $\begin{array}{l}\mathrm{KMO}=.778 \\
\text { Total Variance Explained }=55 \%\end{array}$ & & & & \\
\hline $\begin{array}{l}\text { Extraction Method: Principal Component Analysis. } \\
\text { Rotation Method: Varimax with Kaiser Normalization. }\end{array}$ & & & & \\
\hline
\end{tabular}


Table two shows the mean, standard deviation and correlation of demographic and latent variables. All constructs have standard reliability, escapism motivation has .79; ad skepticism has .77; self-image congruity has .86; and product knowledge has .68.

Table 2 Correlations

\begin{tabular}{|c|c|c|c|c|c|c|c|c|c|c|}
\hline & Variable & Mean SD & 1 & 2 & 3 & 4 & 5 & 6 & 7 & 8 \\
\hline 1 & Age & 2.10 .766 & & & & & & & & \\
\hline 2 & Sex & 1.11 .316 & $-.249^{* *}$ & & & & & & & \\
\hline 3 & Area & 1.57 .496 & $-.123^{*}$ & .019 & & & & & & \\
\hline 4 & Education & $2.35 \quad .924$ & $.412^{* *}$ & $-.252^{* * *}$ & $.174^{* *}$ & & & & & \\
\hline 5 & Escapism Motivation & $3.05 \quad 819$ & -.032 & -.064 & $.121^{*}$ & $.271^{* *}$ & .79 & & & \\
\hline 6 & Ad Skepticism & $3.25 \quad 674$ & $.121^{*}$ & $-.236^{* *}$ & $-.136^{*}$ & $.145^{*}$ & .095 & .77 & & \\
\hline 7 & Self-Image congruity & 2.73 .955 & $-.284^{* *}$ & -.022 & $.149^{*}$ & $.265^{* *}$ & $.513^{* *}$ & .078 & .86 & \\
\hline 8 & Product Knowledge & $2.84 \quad .843$ & $-.190^{* *}$ & -.009 & -.051 & .060 & $.273^{* *}$ & $.138^{*}$ & $.391^{* *}$ & .68 \\
\hline
\end{tabular}

Hypothesis 1 stated that Consumer being motivated with his self-image congruence does not care of for social match up and it strengthen the positive effect on escapism motivation. Table 3 shows that self-image congruence has positive effect on brand escapism motivation. The hypothesis was supported by the results exhibited in the Table 3 .

Hypothesis 2 stated that Ad skepticism has significant mediating effect on self-image congruity and brand escapism motivation. The results of hierarchical regression analysis do not support the relationship (See Table 3). This may be the reason that people in Pakistan are not much paying attention to advertising appeals and they only care of an event match up and are not consistent with self-image congruence. Item (The image of the mobile phone brand is consistent with my self-image) in scale of self-image congruence has been dropped in exploratory factor analysis. Which was supported in the study of Labrecque et al. (2011) at United States.

Hypothesis 3 stated that Consumer is escaping from his social gatherings with the consumption of many products and its more knowledge creates positive effect on brand escapism motivation. The results of hierarchical regression analysis supported the relationship (See Table 4) that product knowledge creates positive significant effect on brand escapism motivation. The hypothesis was supported by the results exhibited in the Table 4 . 
Similarly hypothesis 4 stated that Ad skepticism has significant mediating effect on product knowledge and brand escapism motivation was also examined by hierarchical regression analysis. The results showed in Table 4 states that Ad skepticism has no significant mediating effect on product knowledge and brand escapism motivation. Respondents have shown that they are less caring in the product knowledge of substitute brands; the items, (1. I feel very confident about my ability to tell the difference in quality among different land line telephones, 2. I have a lot of knowledge about how to select the best brand of land line telephone to suit my needs) have been dropped in exploratory factor analysis. This is the reason that mediating effect has not been supported.

Table 3

\begin{tabular}{|c|c|c|c|c|c|c|c|c|c|}
\hline \multicolumn{10}{|c|}{ Brand Escapism Motivation } \\
\hline & \multicolumn{3}{|c|}{ Step 1} & \multicolumn{3}{|c|}{ Step 2} & \multicolumn{3}{|c|}{ Step 3} \\
\hline & $\beta$ & $\mathbf{t}$ & $\rho$ & $\beta$ & $\mathbf{t}$ & $\rho$ & $\beta$ & $\mathbf{t}$ & $\rho$ \\
\hline Age & -.16 & -2.49 & .013 & .073 & 1.099 & .273 & .071 & 1.072 & .285 \\
\hline Gender & -.02 & -.39 & .694 & -.011 & -.193 & .847 & -.003 & -.050 & .961 \\
\hline Area & .044 & .729 & .467 & .038 & .707 & .480 & .044 & .808 & .420 \\
\hline Education & .325 & 4.830 & .000 & .099 & 1.492 & .137 & .095 & 1.440 & .151 \\
\hline Self & & & & .502 & 8.281 & .000 & .499 & 8.191 & .000 \\
\hline \multirow{2}{*}{\multicolumn{10}{|c|}{$\begin{array}{l}\text { Image } \\
\text { Congurity }\end{array}$}} \\
\hline & & & & & & & & & \\
\hline $\begin{array}{l}\text { Ad } \\
\text { Skeptism }\end{array}$ & & & & & & & .039 & .713 & .477 \\
\hline $\mathrm{R}$ & .317 & & & .536 & & & .537 & & \\
\hline $\mathrm{R}^{2}$ & .100 & & & .288 & & & .289 & & \\
\hline $\operatorname{Adj} R^{2}$ & .087 & & & .274 & & & .272 & & \\
\hline$\Delta \mathrm{R}^{2}$ & .100 & & & .187 & & & .001 & & \\
\hline $\begin{array}{c}\bar{c} \\
\text { ble } 4\end{array}$ & 7 ane & & & C & & & $17 \mathrm{cn}$ & & \\
\hline
\end{tabular}

4.

5.

6.

Brand Escapism Motivation

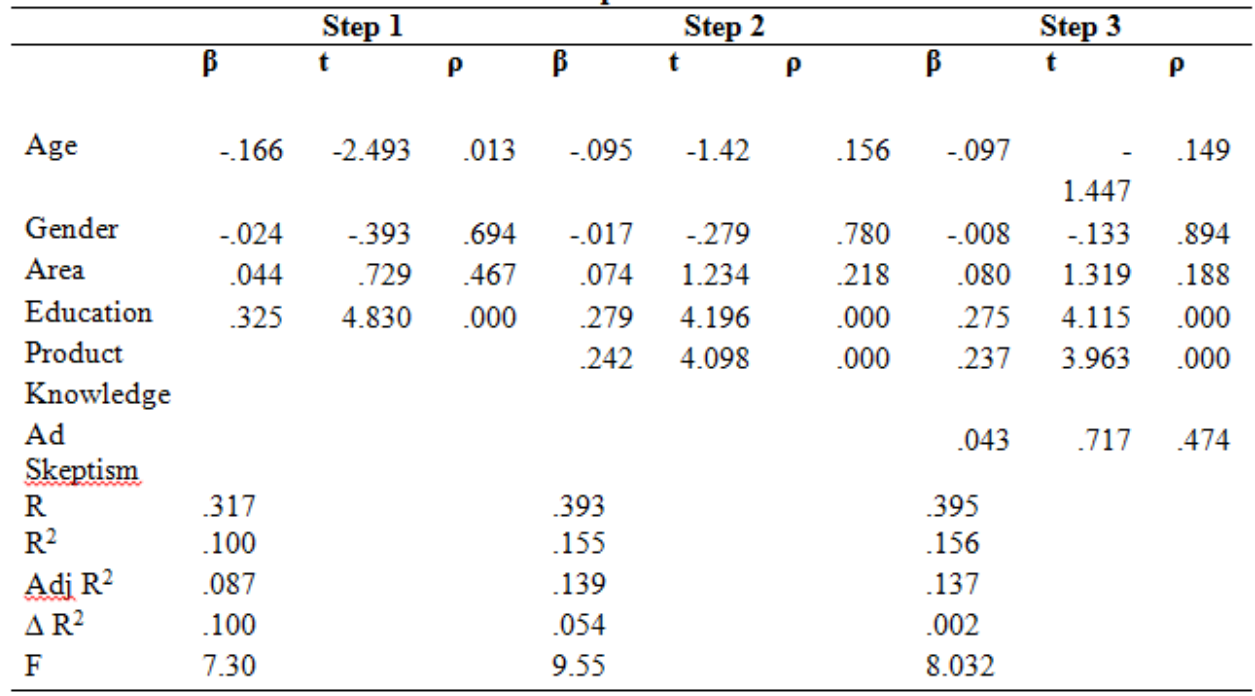

Sample size 267

Level of Confidence for Confidence Intervals: 95 


\section{Conclusion}

This study is conducted to see the mediating effect of ad skepticism between self-image congruence, product knowledge and brand escapism motivation. Consumers in Pakistan are motivated in escaping from brands; product knowledge and self-image congruity has positive effect on it. Self-image congruity places positive effect when it is not matched between marketer offer and an individual self. This is because of certain mediums, such as ad skepticism, which is studied as mediating effect in this study. This mediating effect is not supported in our study; it is due to consumers less interest of self-image consistency and product knowledge of substitute products. Both constructs, self-image congruency and product knowledge two items has been dropped in exploratory factor analysis, which represents the consistency of self-image congruency and product knowledge of substitute products. The other reason may be that consumers do not try to get the product knowledge because of their less interest in brands expect as an icon of social status or being a collectivist society they believe on other sources of purchase decisions instead of their own product knowledge collection and evaluation, such as peer suggestion and word of mouth. The more products in the market and more its knowledge creates halo of resemblance which has positive effect on escapism motivation, the results in our study also support it.

\section{Practical Implication}

This research is helpful for all marketers to position their brand in such a way that consumer should not be motivated in escaping the brands and for advertising agencies to clearly understand the product knowledge excess which is becoming the cause to hallo of resemblance. Managers try to increase the customer loyalty, escapists are the one who not only leave the usage of brands but also places influence through negative word of mouth, managers can take help from this study and try to retain the customers and save users of brands from escapist arguments. Apart from this it also share contribution in the marketing literature as well.

\section{Research Limitation}

Product knowledge and self-image congruence are very broad constructs and have their sub parts, like product knowledge has product experience, subjective knowledge, objective knowledge. And self-image congruence has actual self-image and ideal self-image or high and low level of self-image congruence. Our research is focusing on only general concept of these constructs. If they are studied with their division and the mediation role of ad skepticism is examined, this can bring new aspects of research. Sample used in this study is enough for statistical analysis but for further generalization, it may be increased. 


\section{Future Research}

The mediating role of ad skepticism can be checked by classifying the self-image and product knowledge; as it is discussed in our area of research limitations. This kind of study can bring new results in a developed country, where consumers tend to spend more time on the selection of brands and study more information of products and they try to relate brands with their personality with consistency. 


\section{References}

Barksdale, H. C., \& Darden, W. R. (1972). Consumer attitudes toward marketing and consumerism. The Journal of Marketing, 28-35.

Bauer, R. A., Greyser, S. A., Kanter, D. L., Weilbacher, W. M., Courtney, A. E., \& Gale, C. (1968). Advertising in America: The consumer view: Division of Research, Graduate School of Business Administration, Harvard University Boston.

Bemmaor, A. C., \& Mouchoux, D. (1991). Measuring the short-term effect of in-store promotion and retail advertising on brand sales: A factorial experiment. Journal of Marketing research, 202-214.

Brester, G. W., \& Schroeder, T. C. (1995). The impacts of brand and generic advertising on meat demand. American Journal of Agricultural Economics, 77(4), 969-979.

Campbell, M. C., \& Keller, K. L. (2003). Brand familiarity and advertising repetition effects. Journal of Consumer Research, 30(2), 292-304.

Casswell, S., \& Zhang, J. F. (2002). Impact of liking for advertising and brand allegiance on drinking and alcohol-related aggression: a longitudinal study. Addiction, 93(8), 1209-1217.

Chaudhuri, A. (2002). How brand reputation affects the advertising-brand equity link. Journal of Advertising Research, 42(3).

Chioveanu, I. (2008). Advertising, brand loyalty and pricing. Games and Economic Behavior, 64(1), 68-80.

Cobb-Walgren, C. J., Ruble, C. A., \& Donthu, N. (1995). Brand equity, brand preference, and purchase intent. Journal of Advertising, 25-40.

Cox, D. F., \& Rich, S. U. (1964). Perceived risk and consumer decision-making: The case of telephone shopping. Journal of Marketing Research, 32-39.

Dahlén, M., \& Lange, F. (2004). To challenge or not to challenge: Ad-brand incongruency and brand familiarity. Journal of Marketing Theory and Practice, 20-35.

Dahlén, M., Lange, F., Sjödin, H., \& Törn, F. (2005). Effects of Ad-Brand Incongruence. Journal of Current Issues \& Research in Advertising, 27(2), 1-12.

Deighton, J., Henderson, C. M., \& Neslin, S. A. (1994). The effects of advertising on brand switching and repeat purchasing. Journal of Marketing research, 28-43. 
Feick, L., \& Gierl, H. (1996). Skepticism about advertising: A comparison of East and West German consumers. International journal of research in marketing, 13(3), 227-235.

Foxman, E. R., Berger, P. W., \& Cote, J. A. (1992). Consumer brand confusion: A conceptual framework. Psychology and Marketing, 9(2), 123-141.

Foxman, E. R., Muehling, D. D., \& Berger, P. W. (1990). An investigation of factors contributing to consumer brand confusion. Journal of Consumer Affairs, 24(1), 170-189.

Friestad, M., \& Wright, P. (1995). Persuasion knowledge: Lay people's and researchers' beliefs about the psychology of advertising. Journal of Consumer Research, 62-74.

Gaski, J. F., \& Etzel, M. J. (1986). The index of consumer sentiment toward marketing. The Journal of Marketing, 71-81.

Henning, B., \& Vorderer, P. (2001). Psychological escapism: Predicting the amount of television viewing by need for cognition. Journal of Communication, 51(1), 100-120.

Henry, P. C., \& Caldwell, M. (2006). Self-empowerment and consumption: Consumer remedies for prolonged stigmatization. European Journal of Marketing, 40(9/10), 1031-1048.

Jamal, A., \& Goode, M. M. (2001). Consumers and brands: a study of the impact of selfimage congruence on brand preference and satisfaction. Marketing Intelligence \& Planning, 19(7), 482-492.

Kapferer, J. n. (1995). Brand confusion: empirical study of a legal concept. Psychology and Marketing, 12(6), 551-568.

Keller, K. L. (1987). Memory factors in advertising: The effect of advertising retrieval cues on brand evaluations. Journal of Consumer Research, 316-333.

Khuhro, R. A., Bhutto, N. A., Sarki, I. H., \& Shaikh, I. A. (2012). Escapism and Conformity: Social Motives for Brand Loyalty of Iconic and Less Iconic Brands. Contemporary Business Studies, 6 .

Kirmani, A. (1990). The effect of perceived advertising costs on brand perceptions. Journal of Consumer Research, 160-171.

Koslow, S. (2000). Can the truth hurt? How honest and persuasive advertising can unintentionally lead to increased consumer skepticism. Journal of Consumer Affairs, 34(2), 245-267.

Kozinets, R. V. (2002). Can consumers escape the market? Emancipatory illuminations from burning man. Journal of Consumer Research, 29(1), 20-38. 
Kressmann, F., Sirgy, M. J., Herrmann, A., Huber, F., Huber, S., \& Lee, D.-J. (2006). Direct and indirect effects of self-image congruence on brand loyalty. Journal of Business Research, 59(9), 955-964.

Labrecque, L. I., Krishen, A. S., \& Grzeskowiak, S. (2011). Exploring social motivations for brand loyalty: Conformity versus escapism. Journal of Brand Management, 18(7), 457-472.

Lai, A. W. (1991). Consumption situation and product knowledge in the adoption of a new product. European Journal of Marketing, 25(10), 55-67.

Li, H., Daugherty, T., \& Biocca, F. (2002). Impact of 3-D advertising on product knowledge, brand attitude, and purchase intention: The mediating role of presence. Journal of Advertising, 43-57.

Macdonald, E. K., \& Sharp, B. M. (2000). Brand Awareness Effects on Consumer Decision Making for a Common, Repeat Purchase Product:: A Replication. Journal of Business Research, 48(1), 5-15.

Mathwick, C., \& Rigdon, E. (2004). Play, flow, and the online search experience. Journal of Consumer Research, 31(2), 324-332.

Meenaghan, T. (1995). The role of advertising in brand image development. Journal of Product \& Brand Management, 4(4), 23-34.

Mela, C. F., Gupta, S., \& Lehmann, D. R. (1997). The long-term impact of promotion and advertising on consumer brand choice. Journal of Marketing research, 248-261.

Muehling, D. D. (1987a). Comparative advertising: The influence of attitude-toward-the-ad on brand evaluation. Journal of Advertising, 43-49.

Muehling, D. D. (1987b). An investigation of factors underlying attitude-toward-advertisingin-general. Journal of Advertising.

Obermiller, C., \& Spangenberg, E. R. (1998). Development of a scale to measure consumer skepticism toward advertising. Journal of consumer psychology, 7(2), 159-186.

Obermiller, C., \& Spangenberg, E. R. (2000). On the origin and distinctness of skepticism toward advertising. Marketing Letters, 11(4), 311-322.

Park, C. W., \& Moon, B. J. (2003). The relationship between product involvement and product knowledge: moderating roles of product type and product knowledge type. Psychology and Marketing, 20(11), 977-997. 
Pechmann, C., \& Ratneshwar, S. (1991). The use of comparative advertising for brand positioning: Association versus differentiation. Journal of Consumer Research, 145-160.

Phelps, J., \& Thorson, E. (1991). Brand familiarity and product involvement effects on the attitude toward an ad-brand attitude relationship. Advances in Consumer Research, 18(1), 202-209.

Sandage, C. H., \& Leckenby, J. D. (1980). Student attitudes toward advertising: Institution vs. instrument. Journal of Advertising, 29-44.

Schiffman, L. G., \& Kanuk, L. L. (2000). Consumer behavior. 7th. edn., Prentice Hall International.

Singh, S., Kristensen, L., \& Villasenor, E. (2009). Overcoming skepticism towards cause related claims: the case of Norway. International Marketing Review, 26(3), 312-326.

Sirgy, M. J. (1982). Self-concept in consumer behavior: A critical review. Journal of Consumer Research, 287-300.

Sirgy, M. J., Grewal, D., \& Mangleburg, T. (2000). Retail environment, self-congruity, and retail patronage: an integrative model and a research agenda. Journal of Business Research, 49(2), 127-138.

Taylor, V. A., \& Bearden, W. O. (2003). Ad spending on brand extensions: Does similarity matter? The Journal of Brand Management, 11(1), 63-74.

Tellis, G. J. (1988). Advertising exposure, loyalty, and brand purchase: a two-stage model of choice. Journal of Marketing research, 134-144.

Thakor, M. V., \& Goneau-Lessard, K. (2009). Development of a scale to measure skepticism of social advertising among adolescents. Journal of Business Research, 62(12), 1342-1349.

Till, B. D., \& Priluck, R. L. (2001). Conditioning of meaning in advertising: Brand gender perception effects. Journal of Current Issues \& Research in Advertising, 23(2), 1-8.

Wann, D., Allen, B., \& Rochelle, A. (2004). Using sport fandom as an escape: Searching for relief from under-stimulation and over-stimulation. International Sports Journal, 8(1), 104113. 